\title{
KARAKTERISTIK OLEOGEL DARI MINYAK NABATI MENGGUNAKAN LILIN LEBAH DAN LEMAK KAKAO SEBAGAI OLEOGELATOR
}

\author{
Characteristics of Oleogel Prepared from Vegetable Oil using Beeswax and Cocoa \\ Butter as Oleogelator
}

\author{
Justus Elisa Loppies, Eky Yenita Ristanti, Sitti Ramlah, Alfrida Lullung S., dan \\ Andi Nur Amalia \\ Balai Besar Industri Hasil Perkebunan \\ Jl. Prof. Dr. Abdurahman Basalama No. 28, Makassar 90231 \\ Email: justusloppies@gmail.com
}

\begin{abstract}
Characteristics of oleogel can be determined by restructuring of oil or fat molecules to obtain the special characteristics related to their functions. This research aims to analyze characteristics of oleogels prepared from vegetable oil (palm and soybean oil) with beeswax and cocoa butter as oleogelator. Parameters observed were; texture, melting point, viscosity and solid fat content. The method used in this research is laboratory experiment by comparing the oleogelation process using two types of vegetable oil; palm oil and soybean oil and two types of oleogelator composition: $1 \%$ cocoa fat $+9 \%$ beeswax and $3 \%$ cocoa fat $+7 \%$ beeswax. The oleogelation process was carried out by mixing the oil mass with the oleogelator at 15,000 and 25,000 rpm. The results showed that oleogel with the best characteristic was from the process of palm oil oleogration with $1 \%$ cocoa fat + $9 \%$ beeswax oleogelators at a stirring speed of 25,000 rpm. Characteristics of obtained oleogel were: a high melting point and viscosity of $43.72-45.53^{\circ} \mathrm{C}$ and $161 \times 103$ centipoise, as well as a denser and more homogeneous structure with a lower solid fat content (83.33\%).
\end{abstract}

Keywords: characteristics, oleogel, vegetable oil, beeswax, cocoa butter.

\begin{abstract}
Abstrak: Karakteristik oleogel dapat ditentukan dengan cara menata ulang struktur molekul minyak atau lemak sehingga diperoleh karakteristik tertentu sesuai peruntukannya. Penelitian ini bertujuan untuk menganalisa karakteristik oleogel yang dibuat dari bahan minyak nabati (minyak sawit dan kedelai) dan lilin lebah dan lemak kakao sebagai oleogelator. Parameter yang diamati meliputi; tekstur, titik leleh, viskositas dan kandungan lemak padat. Metode yang digunakan adalah eksperimen laboratorium dengan membandingkan proses oleogelasi menggunakan dua jenis minyak nabati yaitu: minyak sawit dan minyak kedelai dan dua jenis komposisi oleogelator yaitu lemak kakao $1 \%+$ lilin lebah $9 \%$ dan lemak kakao $3 \%$ + lilin lebah $7 \%$. Proses oleogelasi dilakukan dengan cara mencampurkan massa minyak dengan oleogelator pada putaran 15.000 dan $25.000 \mathrm{rpm}$. Hasil penelitian menunjukkan bahwa oleogel dengan karakteristik terbaik adalah dari proses oleogelasi minyak sawit dengan oleogelator (1\% lemak kakao dan 9\% lilin lebah) pada kecepatan pengadukan $25.000 \mathrm{rpm}$. Karakteristik dari oleogel yang diperoleh adalah; titik leleh dan viskositas yang tinggi yaitu $43,72-45,53{ }^{\circ} \mathrm{C}$ dan 161 $\times 10^{3}$ centipoise, serta struktur yang lebih padat dan homogen dengan kandungan lemak padat yang lebih rendah $(83,33 \%)$.
\end{abstract}

Kata Kunci: karakteristik, oleogel, minyak nabati, lilin lebah, lemak kakao.

\section{PENDAHULUAN}

Oleogel dapat didefinisikan sebagai lemak lipofilik dan campuran padat, dimana material lemak padat (oleogelator) dengan konsentrasi yang lebih rendah $(<10 \%)$ dapat menyerap dengan cara membentuk jejaring oleogelator pada minyak curah. Mekanisme pembentukan oleogel (oleogelasi), meliputi gelasi dari minyak dengan bantuan gelator tunggal atau kombinasi sinergis dari beberapa molekul gelator yang berbeda
(Patel, 2014). Pengembangan oleogel pada mulanya untuk kepentingan di bidang farmasi dan kosmetik (US No. 006187323B1, 2001), namun pengembangannya mulai meluas sebagai bahan untuk pembuatan makanan, karena memiliki potensi untuk mengurangi penggunaan lemak jenuh yang tidak baik bagi kesehatan (Van, 2016; Blake, 2015; Davidovich et al., 2016).

Beberapa penelitian terkait oleogel berbasis minyak nabati telah dilakukan 
dengan memanfaatkan sumber-sumber oleogelator seperti lilin candellila (Candellila wax) (Toro-Vazquez et al, 2009), lilin mata beras (rice bran wax) (Kodai, 2009; Dassanayake, 2009), lilin bunga matahari (sun falwer) wax dan lilin Carnauba (Carnauba wax). Umumnya yang diteliti adalah proses gelasi minyak nabati menjadi oleogel menggunakan oleogelator tunggal, sedangkan terkait pemanfaatan lilin lebah dan lemak kakao maupun kombinasi keduanya masih sangat minim.

Penelitian ini menggunakan minyak nabati (minyak kedelai dan minyak sawit) dan kombinasi gelator berupa lilin lebah (bees wax) dan lemak kakao. Pentingnya pengembangan oleogel dan oleogelator berbasis minyak nabati berkaitan dengan sifat lemaknya yang lebih mudah berinteraksi dengan bahan lain, mudah dibentuk sesuai dengan karakteristik yang diinginkan, lebih murah bila dibandingkan dengan lemak non nabati lainnya, dan memiliki fungsi kesehatan. Dilaporkan oleh Maragoni (2012), penataan minyak nabati dengan suatu organogelator menjadi strategi penelitian yang penting untuk mengganti lemak trans tanpa meningkatkan jumlah lemak jenuh.

Penggunaan jenis minyak sawit dan minyak kedelai dalam penataan struktur oleogel karena kedua jenis minyak nabati ini memiliki sifat-sifat yang berbeda. Minyak sawit memiliki komposisi asam lemak jenuh dan asam lemak tidak jenuh yang seimbang dengan komponen utamanya adalah asam palmitat (44-45\%), asam oleat (39-40\%), asam linoleat (10-11\%) dan sejumlah kecil asam linolenat (Gunstone, 2002). Keseimbangan kandungan asam lemak jenuh dan asam lemak tidak jenuh pada minyak sawit memungkinkan jenis minyak ini lebih stabil dibanding dengan jenis minyak nabati lainnya (Wulandari et al., 2011). Sedangkan minyak kedelai didominasi oleh $85-90 \%$ asam lemak tidak jenuh dengan fraksi cair dibanding dengan jenis minyak nabati lain seperti minyak kelapa. Dominasi asam lemak jenuh pada minyak sawit akan membentuk sifat minyak yang semi solid atau kental dibanding dengan minyak kedelai yang agak cair. Hal ini akan berdampak pada pembentukan kristal oleogel dengan sifat yang berbeda.

Dukungan kombinasi material oleogelator (lilin lebah dan lemak kakao) untuk menggelasi minyak nabati merupakan dasar pembentukan oleogel. Hal ini berkaitan dengan sifat bahan yang mudah membentuk tekstur oleogel. Selain itu, tuntutan konsumen lebih condong ke arah lilin berbasis bio dibanding lilin berbasis mineral untuk penggunaannya dalam industri makanan, farmasi dan kosmetik (Samuditha, Dassanayake, Kodali, \& Ueno, 2011).

Dalam industri makanan, oleogel berbasis lilin dapat digunakan untuk menggantikan sebagian atau seluruhnya lemak trans dan atau lemak jenuh dalam formulasi makanan berbasis lemak seperti shortening, margarin, produk manisan, es krim, dan whipped-cream. Selain itu, migrasi minyak dapat dicegah dengan menggunakan kristal lilin untuk menangkap minyak cair dalam isian permen berbasis lemak (Doan, et al., 2018).

Penggunaan lilin lebah dan lemak kakao sebagai oleogelator didasarkan pada sifat-sifat dari kedua bahan tersebut yang cenderung membentuk kristal padat dan lebih mudah berinteraksi untuk restrukturisasi minyak nabati menjadi oleogel. Lilin lebah memiliki titik lebur yang rendah antara $62-64$ ${ }^{\circ} \mathrm{C}$. Komponen utamanya berupa palmintat, palmitoleat dan ester dari asam oleat dengan panjang rantai karbon antara $30-32$. Diketahui, lilin lebah mengandung sekitar 71 $\%$ ester rantai panjang, $12 \%$ asam lemak bebas, dan $14 \%$ hidrokarbon (Jana and Martini., 2016a; Ogutcu et al., 2015; Blake et al., 2014) sehingga mampu membentuk struktur kristal jaringan tiga dimensi oleogel yang lebih padat. Kombinasi lilin lebah dengan lemak kakao akan memperkuat pembentukan struktur jaringan oleogel.

Potensi lemak kakao sebagai oleogelator karena memiliki beberapa komponen utama antara lain: asam stearat (34\%), asam oleat $34 \%$, asam palmitat (25\%) 
dan asam oleat (2\%) (Ross, 2000). Asam stearat dari lemak kakao tergolong asam lemak jenuh yang memberikan struktur padat pada lemak kakao. Asam lemak dengan tingkat kejenuhan yang tinggi menghasilkan material dengan titik leleh yang lebih tinggi, sehingga apabila diaplikasikan sebagai oleogelator akan membentuk material dengan viskositas dan titik leleh yang tinggi. Kombinasi lemak kakao dengan material lain yang mengandung asam lemak tidak jenuh yang tinggi seperti minyak kedelai dan minyak sawit akan menghasilkan material dengan sifat atau tekstur yang tidak memadat maupun tidak mencair atau berada pada kondisi dengan kekentalan yang stabil. Sifat ini dapat ditata ulang atau direkonstruksi sesuai peruntukannya. Tujuannya adalah untuk memperbaiki sifat struktur lemak dan minyak nabati, sehingga memberikan tekstur yang lebih baik sesuai peruntukannya seperti untuk diplikasikan pada pembuatan produk makanan cokelat oles, es krim dan sosis.

Penataan struktur oleogel berbasis minyak sawit dan minyak kedelai dengan kombinasi oleogelator merupakan alasan untuk menghadirkan suatu material pengganti lemak yang memiliki karakteristik sesuai peruntukannya, sehingga perlu diketahui sifat-sifat atau karakteristik fisik berdasarkan perlakuan yang diberikan.

Karakteristik fisik ini berkaitan dengan fungsi dan interaksi oleogel dengan bahan lain yang akan dibentuk menjadi suatu produk baru, bahan pengisi atau bahan tambahan. Karakter fisik yang dimaksud meliputi viskositas, kekakuan, kelarutan, dan kemampuan berinteraksi dengan bahan lain. Penentuan sifat fisik ini akan memberikan informasi dalam mengaplikasikan sesuai peruntukannya.

Penelitian ini bertujuan untuk mengungkap karakteristik oleogel yang dibentuk dari bahan minyak nabati (minyak sawit dan kedelai) dan lilin lebah dan lemak kakao sebagai oleogelator.

\section{METODOLOGI}

\section{Tempat dan Waktu Penelitian}

Penelitian ini telah dilaksanakan di Laboratorium Penelitian dan Pengembangan Balai Besar Industri Hasil Perkebunan di Makassar dan di laboratorium Farmasi Institut Teknologi Bandung (ITB) mulai bulan Januari sampai dengan Oktober 2018.

\section{Alat dan Bahan}

Alat-alat yang digunakan antara lain ultra turraxdigital, Model: T25D buatan Jerman, penangas air (Thermostatic water bath, Model: HWS-24, Merek Drawell, buatan Shanghai), Hot Plate (Thermo, Model No: SP88857105 Merek Cimarec, buatan China), magnetic stirrer, gelas plastik steril $150 \mathrm{ml}$, botol kaca vakum, tabung EppendorfPCR tube 1,5 ml dan alat sentrifus (Hettich Zentrifugen EBA 200, buatan Jerman).

Penelitian ini dilaksanakan dengan metode percobaan pada skala laboratorium. Kegiatan penelitian dilaksanakan melalui kajian beberapa literatur, pelaksanaan penelitian, dan analisis karakteristik produk.

Bahan-bahan yang digunakan untuk pembuatan oleogel terdiri dari: minyak kedelai dan minyak sawit yang dikomersilkan sebagai minyak pangan; lilin lebah (bees wax) dan lemak kakao sebagai gelator atau oleogelator untuk membentuk emulsi; dan Tertier Butyl Hydroxy Quninolin (TBHQ) sebagai antioksidan untuk minyak dan lemak.

\section{Tahapan Pelaksanaan Penelitian}

Pembuatan oleogel, oleogator, dan Perlakuan Percobaan

Pembuatan oleogel dimulai dengan cara menyiapkan bahan-bahan yang terdiri dari; lilin lebah dan lemak kakao sebagai oleogelator dan minyak nabati (minyak sawit dan minyak kedelai).

Lemak kakao dan lilin lebah dipanaskan terpisah pada suhu $90{ }^{\circ} \mathrm{C}$ hingga mencair sempurna. Kedua oleogator tersebut dalam keadaan mencair kemudian dicampur dan diaduk hingga homogen dengan komposisi sesuai perlakuan yaitu; gelator pertama 
(O1) terdiri dari 1\% lemak kakao $+9 \%$ lilin lebah (total 10\%); dan gelator kedua (O2) terdiri dari $3 \%$ lemak kakao $+7 \%$ lilin lebah (total $10 \%$ ). Proses oleogelasi dilakukan dengan cara mencampurkan masing-masing oleogator ke dalam $90 \%$ minyak kedelai (K1) maupun ke dalam 90\% minyak sawit (S1) pada wadah yang berbeda, kemudian dipanaskan pada penangas air dengan suhu $90{ }^{\circ} \mathrm{C}$ sambil diaduk dengan ultra turrax pada kecepatan $1.500 \mathrm{rpm}$ (V1) dan 25.000 rpm (V2) selama 5 menit. Oleogel yang terbentuk kemudian disimpan pada suhu kamar selama 24 jam hingga oleogel terbentuk sempurna. Kombinasi perlakuan membentuk delapan satuan percobaan (sampel) yaitu: K101V1 $(90 \%$ minyak kedelai $+1 \%$ lemak kakao + 9\% lilin lebah, diaduk pada kecepatan 1.500 rpm); K1O1V2 (90\% minyak kedelai $+1 \%$ lemak kakao $+9 \%$ lilin lebah, diaduk pada kecepatan $25.000 \mathrm{rpm}$ ); K1O2V1 (90\% minyak kedelai $+3 \%$ lemak kakao $+7 \%$ lilin lebah, diaduk pada kecepatan $1.500 \mathrm{rpm}$ ); K1O2V2 (90\% minyak kedelai $+3 \%$ lemak kakao $+7 \%$ lilin lebah, diaduk pada kecepatan $25.000 \mathrm{rpm}$ ); S101V1 (90\% minyak sawit $+1 \%$ lemak kakao $+9 \%$ lilin lebah, diaduk pada kecepatan $1.500 \mathrm{rpm}) ;$ S1O1V2 (90\% minyak sawit $+1 \%$ lemak kakao $+9 \%$ lilin lebah, diaduk pada kecepatan $25.000 \mathrm{rpm}$ ); S1O2V1 (90\% minyak sawit $+3 \%$ lemak kakao $+7 \%$ lilin lebah, diaduk pada kecepatan $1.500 \mathrm{rpm}) ;$ S1O2V2 (90\% minyak sawit $+1 \%$ lemak kakao $+9 \%$ lilin lebah, diaduk pada kecepatan $25.000 \mathrm{rpm}$ ).

\section{Pengujian Oleogel}

Parameter uji yang dilakukan untuk mengevaluasi kualitas oleogelyang dihasilkan meliputi: analisis tekstur dan analisis struktur atau morfologi kristal dengan scanning electron microscopy pada pembesaran 1000 sampai $20.000 x$, analisa termal dengan alat differential scanning calorimetry, viskositas, dan kandungan lemak padat (solid fat content) menggunakan metode NMR.

\section{HASIL DAN PEMBAHASAN}

\section{Pembentukan Struktur Oleogel}

Tampilan micrograf scanning electron microscopy untuk struktur kristal oleogel dimulai dengan pembesaran 1000x, 2000x, 8000x dan 20.000x. Hasil pengamatan menunjuk-kan, terjadi pembentukkan struktur secara berkelompok (cluster) tetapi belum menyatu dengan struktur yang kompak (tidak homogen) (Gambar 1a, 1b, dan 1c). Umumnya struktur atau profil oleogel berbentuk bulat, setengah bulat dan sebagian berupa kubuskubus kecil. Pembentukan cluster diduga berkaitan dengan proses penyatuan molekul yang belum sempurna sebagai akibat proses pengadukan belum optimal (15.000 rpm). Proses homogenasi berkaitan dengan proses pemecahan molekul menjadi mikro sampai nano molekul. Hal ini sangat bergantung pada jenis alat, kecepatan pengadukan dan waktu. Pada kenyataannya, oleogel dengan struktur molekul dalam bentuk cluster atau parsial tidak membentuk tekstur dengan viskositas yang baik. Penanganan terhadap masalah ini adalah dengan mempertimbangkan penggunaan jenis oleogelator atau gelator dan penggunaan pengadukan bertekanan atau dengan sistem pengadukan kecepatan tinggi (25.000 rpm).

Mikrograf dengan pembesaran sampai 20.000x (Gambar 1e dan 1f) menunjukkan bahwa pada struktur mikro molekul oleogel telah terjadi interaksi yang sangat kuat antar molekul bahan penyusun oleogel, dimana terjadi penyatuan struktur secara merapat sehingga membentuk jaringan kristal tiga dimensi dengan susunan yang tidak beraturan. Di antara kedua pola struktur yang terbentuk tersebut, Gambar 1e (S101V1) yang merupakan sampel oleogel yang tersusun dari minyak sawit $90 \%$ dan oleogator $10 \%$ (1 \% lemak kakao dan 9 $\%$ lilin lebah), memperlihatkan pola yang merapat dan menyatu dibanding dengan pola yang terbentuk pada formasi lainnya. Hal ini meununjukkan bahwa penggunaan minyak sawit dengan oleogelator ( $1 \%$ lemak kakao dan $9 \%$ lilin lebah) cenderung membentuk sifat oleogel yang lebih stabil dan homogen. 
Didukung oleh hasil uji viskositas (Gambar 3) dimana diperoleh oleogel dengan viskositas tertinggi terdapat pada perlakuan penggunaan minyak sawit dengan oleogelator ( $1 \%$ lemak kakao dan $9 \%$ lilin lebah) yang diproses dengan kecepatan aduk pada $25.000 \mathrm{rpm}$. Hal ini menunjukkan bawa terdapat perbedaan antara penggunaan minyak kedelai dan minyak sawit, perbedaan komposisi oleogelator dan kecepatan pengadukan dalam proses pembentukan struktur oleogel. Ditinjau dari jenis asam lemak penyusun kedua jenis minyak tersebut, minyak sawit didominasi oleh $50 \%$ asam lemak jenuh dan $50 \%$ asam lemak tidak jenuh, sedangkan minyak kedelai didominasi oleh $85-90 \%$ asam lemak tidak jenuh dan $10-15 \%$ asam lemak jenuh. Asam lemak jenuh cenderung membentuk fraksi padat sedangkan asam lemak tidak jenuh membentuk fraksi cair. Dominasi asam lemak jenuh pada minyak sawitakan membentuksifat minyak yang semi solid atau kental dibanding dengan minyak kedelai yang agak cair. Hal ini berakibat pada terbentuknya tekstur oleogel yang lebih baik dibanding penggunaan minyak kedelai dalam memproduksi oleogel. Selain itu, pengaruh yang kuat dari penambahan oleogelator ( $9 \%$ lilin lebah dan $1 \%$ lemak kakao) mengindikasikan bahwa lilin lebah cenderung lebih berpengaruh dari lemak kakao dalam membentuk tekstur oleogel. Hasil percobaan menunjukkan bahwa penggunaan lemak kakao 1 - $3 \%$ tidak mempengaruhi tekstur oleogel. Diketahui bahwa, lilin lebah mengandung sekitar $71 \%$ ester rantai panjang, $12 \%$ asam lemak bebas, dan $14 \%$ hidrokarbon (Jana and Martini., 2016a; Ogutcu et al., 2015; Blake et al., 2014) sehingga mampu membentuk struktur kristal jaringan tiga dimensi oleogel yang lebih padat dibanding lemak kakao. Salah satu bentuk bangunan oleogel yang membentuk struktur tiga dimensi adalah partikel kristal seperti triasilgliserida (TAG) yang yang memerangkap minyak cair (Narine dan Marangoni, 1999). Contoh jaringan kristal yang dikembangkan adalah oleogel berbahan lilin nabati seperti lilin candellila (Candellila wax), lilin mata beras (rice bran wax) dan lilin lebah (beeswax).

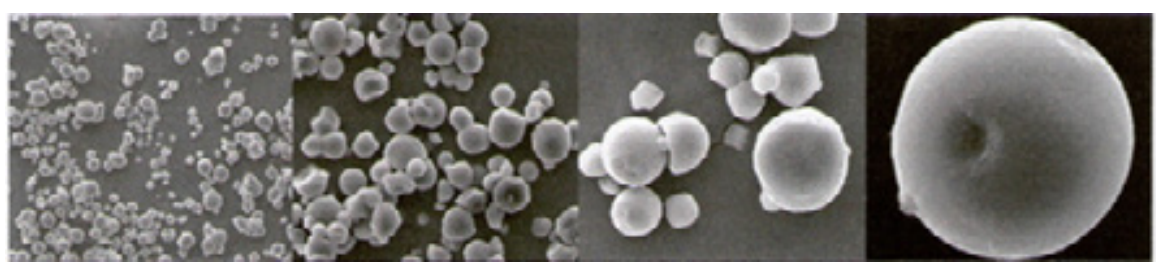

Gambar 1a. Hasil foto SEM sampel K1O1V1 (90\% minyak kedelai + 1\% lemak kakao + 9\% lilin lebah, diaduk pada kecepatan $1.500 \mathrm{rpm}$ )

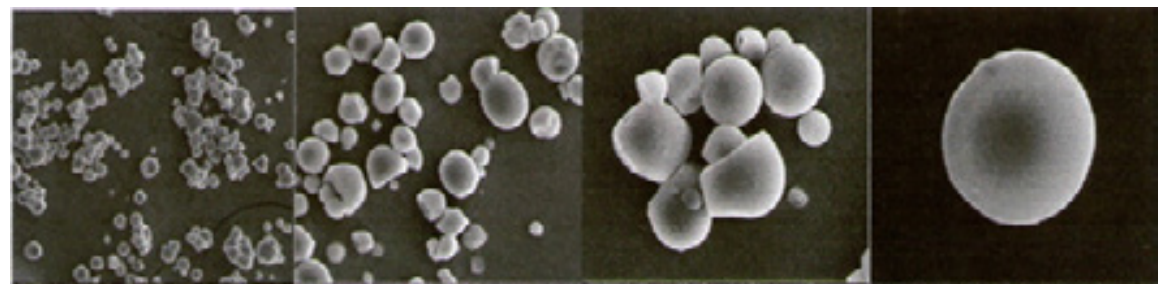

Gambar 1b. Hasil foto SEM sampel K1O1V2 (90\% minyak kedelai + 1\% lemak kakao + 9\% lilin lebah, diaduk pada kecepatan $25.000 \mathrm{rpm}$ )

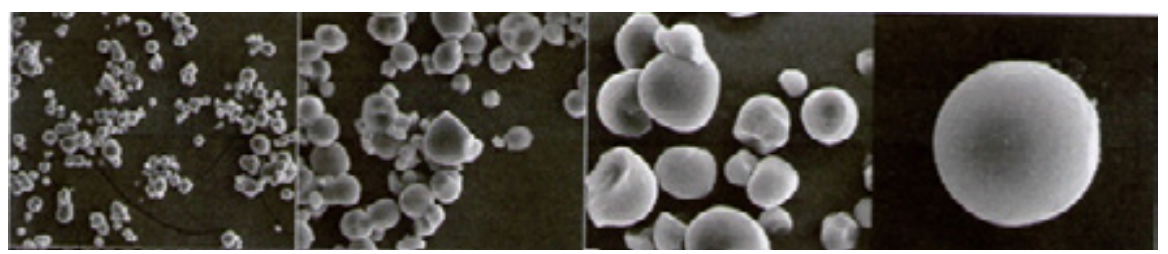

Gambar 1c. Hasil foto SEM sampel K1O2V1 (90\% minyak kedelai $+3 \%$ lemak kakao $+7 \%$ lilin lebah, diaduk pada kecepatan $1.500 \mathrm{rpm}$ ) 


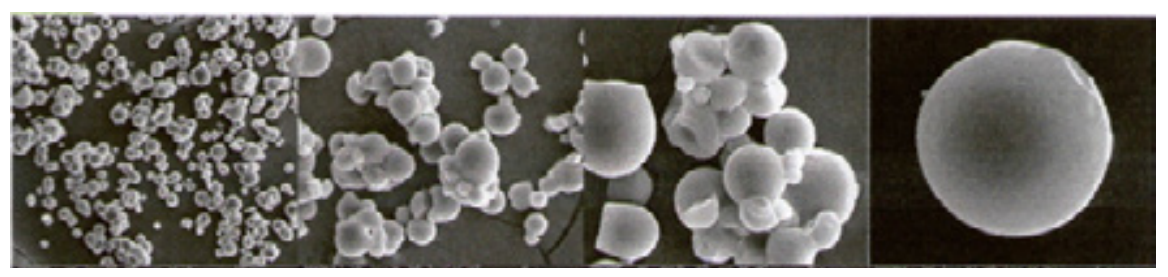

Gambar 1d. Hasil foto SEM sampel K1O2V2 (90\% minyak kedelai + 3\% lemak kakao + 7\% lilin lebah, diaduk pada kecepatan $25.000 \mathrm{rpm}$ ).

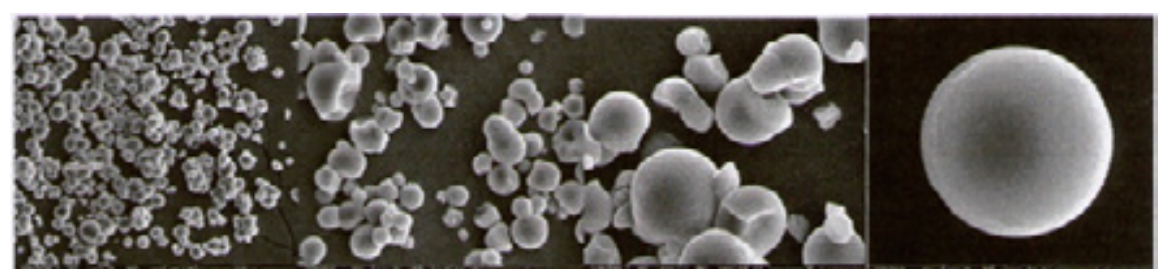

Gambar 1e. Hasil Foto SEM sampel S101V1 (90\% minyak sawit + 1\% lemak kakao + 9\% lilin lebah, diaduk pada kecepatan $1.500 \mathrm{rpm}$ ).

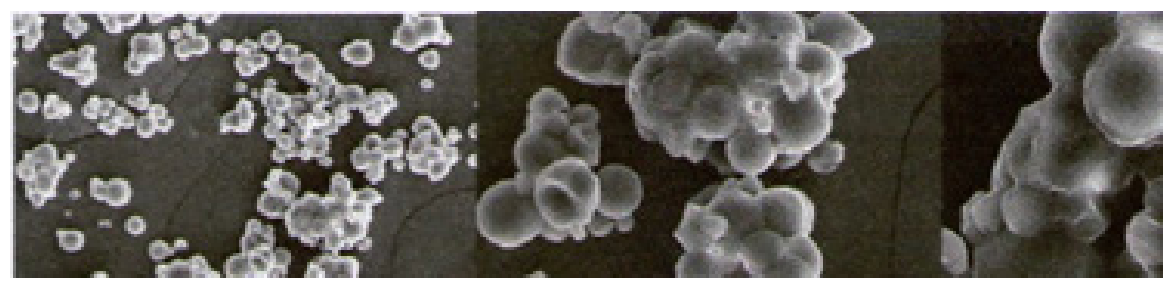

Gambar 1f. Hasil foto SEM sampel S101V2 (90\% minyak sawit + 1\% lemak kakao + 9\% lilin lebah, diaduk pada kecepatan $25.000 \mathrm{rpm}$ ).

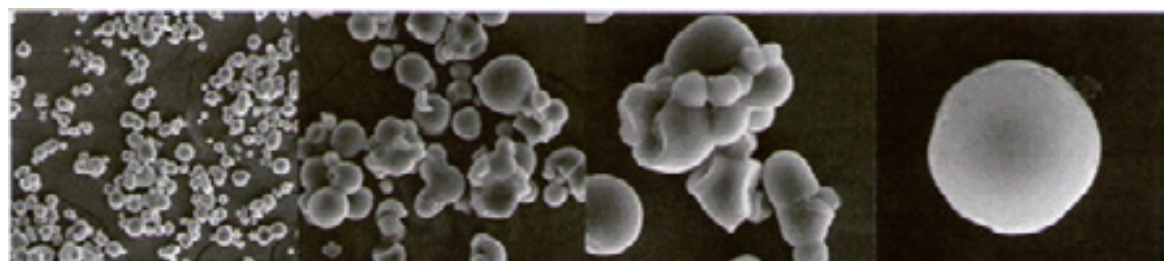

Gambar 1g. Hasil foto SEM sampel S1O2V1 (90\% minyak sawit + 3\% lemak kakao + 7\% lilin lebah, diaduk pada kecepatan $1.500 \mathrm{rpm})$.

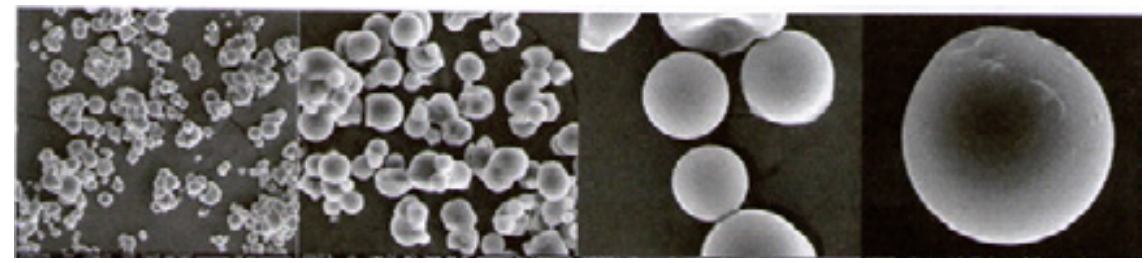

Gambar 1h. Hasil foto SEM sampel S1O2V2 (90\% minyak sawit + 1\% lemak kakao + 9\% lilin lebah, diaduk pada kecepatan $25.000 \mathrm{rpm}$ ).

\section{Titik Leleh}

Pentingnya titik leleh berkaitan dengan kemampuan oleogel untuk berinteraksi dengan bahan lain maupun untuk memenuhi fungsi dari suatu karakter produk yang akan dibentuk. Suhu, entalpi leleh dan kristalisasi adalah parameter termal yang terkait dengan polaritas molekul dan energi interaksi molekul untuk membentuk struktur kristal gelator (Toro-Vazquesz et al., 2013). 


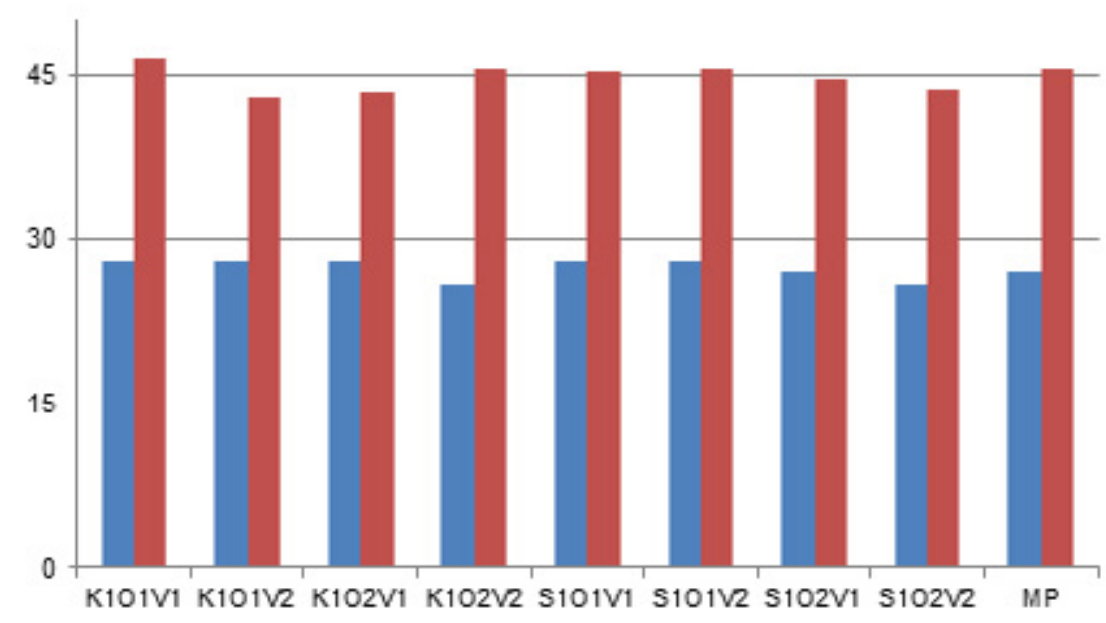

Gambar 2. Kondisi termal (titik leleh dan titik leleh sempurna) oleogel dari berbagai perlakuan oleogasi

Keterangan Gambar :

K1O1V1 $=(90 \%$ minyak kedelai $+1 \%$ lemak kakao $+9 \%$ lilin lebah, diaduk pada kecepatan $1.500 \mathrm{rpm})$ $\mathrm{K} 1 \mathrm{O} 1 \mathrm{~V} 2=(90 \%$ minyak kedelai $+1 \%$ lemak kakao $+9 \%$ lilin lebah, diaduk pada kecepatan $25.000 \mathrm{rpm})$ $\mathrm{K} 1 \mathrm{O} 2 \mathrm{~V} 1=(90 \%$ minyak kedelai $+3 \%$ lemak kakao $+7 \%$ lilin lebah, diaduk pada kecepatan $1.500 \mathrm{rpm})$ $\mathrm{K} 1 \mathrm{O} 2 \mathrm{~V} 2=(90 \%$ minyak kedelai $+3 \%$ lemak kakao $+7 \%$ lilin lebah, diaduk pada kecepatan $25.000 \mathrm{rpm})$ S1O1V1 $=(90 \%$ minyak sawit $+1 \%$ lemak kakao $+9 \%$ lilin lebah, diaduk pada kecepatan $1.500 \mathrm{rpm})$ S1O1V2 $=(90 \%$ minyak sawit $+1 \%$ lemak kakao $+9 \%$ lilin lebah, diaduk pada kecepatan $25.000 \mathrm{rpm})$ S1O2V1 $=(90 \%$ minyak sawit $+3 \%$ lemak kakao $+7 \%$ lilin lebah, diaduk pada kecepatan $1.500 \mathrm{rpm})$ S1O2V2 $=(90 \%$ minyak sawit $+1 \%$ lemak kakao $+9 \%$ lilin lebah, diaduk pada kecepatan $25.000 \mathrm{rpm})$. $\mathrm{MP}=$ Mentega Putih sebagai pembanding

Hasil analisis secara umum menunjukkan bahwa titik leleh sempurna oleogel pada berbagai perlakuan oleogelasi mengalami perbedaan yang tidak mencolok antara proses oleogelasi dengan minyak kedelai maupun dengan minyak sawit (Gambar 2). Penggunan oleogelator dengan kecepatan aduk yang berbeda juga tidak menunjukkan pengaruh terhadap perubahan nilai titik leleh oleogel. Kisaran titk leleh oleogel yang menggunakan minyak kedelai berkisar antara 42,88 - 46,60 ${ }^{\circ} \mathrm{C}$ sedangkan titik leleh oleogel dari bahan minyak sawit berkisar antara 43,72 - 45,53 ${ }^{\circ} \mathrm{C}$. Namun jika dilihat dari data atau angka kisaran suhu ini terlihat bahwa nilai titik leleh oleogel dengan bahan minyak sawit pada berbagai perlakuan memiliki bias yang kecil $(s=0,839)$ dan cenderung lebih rapat dibanding dengan kisaran suhu pada oleogel yang berbahan minyak kedelai $(s=1,179)$. Hal ini menunjukkan bahwa sifat oleogel yang diolah dengan bahan minyak sawit agak lebih stabil walaupun memiliki perbedaan yang tidak mencolok dengan oleogel yang berbahan minyak kedelai. Dilaporkan oleh Wulandari et al. (2011), minyak sawit memiliki titik leleh yang cukup tinggi yaitu $25-50{ }^{\circ} \mathrm{C}$ sehingga jenis minyak ini lebih bersifat semi solid dibanding minyak kedelai. Secara umum dapat disimpulkan bahwa, nilai titik leleh oleogel yang diperoleh dari berbagai perlakuan hampir mendekati, bahkan melebihi nilai titk leleh mentega putih (sampel pembanding) (Gambar 2). Hal ini menunjukkan bahwa dari sisi termal, proses oleogelasi dari berbagai perlakuan sudah mendekati sempurna, dimana aplikasi produk diperkirakan dapat meningkatkan ketahanan leleh pada kondisi diatas suhu kamar.

\section{Viskositas}

Hasil analisis viskositas oleogel menunjukkan bahwa penggunaan minyak nabati (minyak sawit dan mnyak kedelai) dan oleogator maupun kecepatan pengadukan mempengaruhi nilai kekentalan (viskositas) 
oleogel. Gambar 3 memperlihatkan penggunaan minyak sawit (S) menghasilkan oleogel dengan kekentalan yang lebih tinggi dari minyak kedelai $(\mathrm{K})$ maupun pembanding mentega putih (MP). Viskositas oleogel yang menggunakan minyak kedelai berkisar antara $30,59 \times 10^{3}-119,00 \times 10^{3}$ centipoise sedangkan viskositas oleogel dari bahan minyak sawit berkisar antara 43,79 $\times 10^{3}$ - 151,00 x $10^{3}$ centipoise. Penambahan oleogator ( $1 \%$ lemak kakao dan $9 \%$ lilin lebah) dalam proses gelasi cenderung membentuk oleogel yang lebih padat dibanding penggunaan oleogelator (3\% lemak kakao dan $7 \%$ lilin lebah). Keunggulan minyak sawit diduga terkait dengan sifat semi solid dengan kandungan asam lemak jenuh yang lebih banyak (50\%), dan stabil dibanding dengan minyak kedelai yang bersifat agak cair dengan kandungan asam lemak jenuh sekitar $10-15 \%$. Dominasi oleogelator ( $1 \%$ lemak kakao dan $9 \%$ lilin lebah) mengindikasikan bahwa pengaruh lilin lebah lebih menonjol dibanding lemak kakao, dimana penggunaan $3 \%$ lemak kakao tidak memberikan efek pembentukan viskositas oleogel yang baik walaupun didukung dengan kecepatan pengadukan yang lebih besar (25.000 rpm) (contoh sampel :K1O2V1, KO2V2 dan S1V2O1, $\mathrm{S} 1 \mathrm{O} 2 \mathrm{~V} 2)$. Keunggulan penggunaan lilin lebah berkaitan dengan densitas yang lebih tinggi dibanding densitas lemak kakao. Dilaporkan oleh Wulandari et al. (2011), bahwa suhu dapat mempengaruhi densitas dimana kenaikan suhu dapat menurunkan densitas. Hal ini sangat membantu kelarutan dan interaksi minyak sawit maupun oleogelator dengan densitas tinggi seperti lemak kakao dan lilin lebah, sehingga apabila suhu diturunkan maka akan terbentuk material oleogel yang kompak dan padat. Namun demikian oleogel dengan kekentalan yang rendah masih memiliki keunggulan sesuai fungsi dan peruntukan untuk produk-produk yang membutuhkan bahan pengisi dengan kekentalan rendah seperti selai, tart, media pengharum, lotion, minyak rambut dan lain-lain. Selain itu, oleogel dengan kekentalan rendah dapat ditata ulang dengan memodifikasi jenis dan komposisi oleogator.

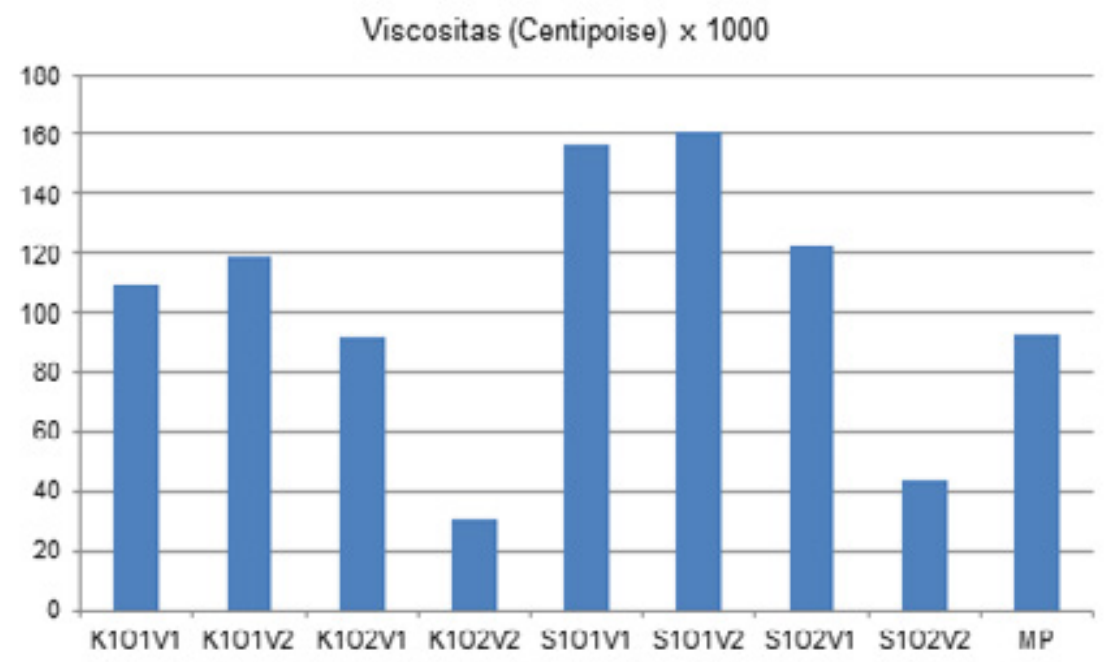

Gambar 3. Viskositas Oleogel yang dihasilkan dari minyak kedelai dan minyak sawit dengan oleogator lemak kakao dan lilin lebah pada kecepatan pengadukan 15.000 dan 25.000 rpm

Keterangan Gambar :

K101V1 $=\quad(90 \%$ minyak kedelai $+1 \%$ lemak kakao $+9 \%$ lilin lebah, diaduk pada kecepatan $1.500 \mathrm{rpm})$ $\mathrm{K} 1 \mathrm{O} 1 \mathrm{~V} 2=(90 \%$ minyak kedelai $+1 \%$ lemak kakao $+9 \%$ lilin lebah, diaduk pada kecepatan $25.000 \mathrm{rpm})$ $\mathrm{K} 1 \mathrm{O} 2 \mathrm{~V} 1=\quad(90 \%$ minyak kedelai $+3 \%$ lemak kakao $+7 \%$ lilin lebah, diaduk pada kecepatan $1.500 \mathrm{rpm})$ 
$\mathrm{K} 1 \mathrm{O} 2 \mathrm{~V} 2=\quad(90 \%$ minyak kedelai $+3 \%$ lemak kakao $+7 \%$ lilin lebah, diaduk pada kecepatan $25.000 \mathrm{rpm})$

S1O1V1 $=(90 \%$ minyak sawit $+1 \%$ lemak kakao $+9 \%$ lilin lebah, diaduk pada kecepatan $1.500 \mathrm{rpm})$

S1O1V2 $=\quad(90 \%$ minyak sawit $+1 \%$ lemak kakao $+9 \%$ lilin lebah, diaduk pada kecepatan $25.000 \mathrm{rpm})$

$\mathrm{S} 1 \mathrm{O} 2 \mathrm{~V} 1=\quad(90 \%$ minyak sawit $+3 \%$ lemak kakao $+7 \%$ lilin lebah, diaduk pada kecepatan $1.500 \mathrm{rpm})$

S1O2V2 $=\quad$ (90\% minyak sawit $+1 \%$ lemak kakao $+9 \%$ lilin lebah, diaduk pada kecepatan $25.000 \mathrm{rpm})$.

$\mathrm{MP}=$ Mentega Putih sebagai pembanding

\section{Kandungan Lemak Padat (Solid Fat Content)}

Hasil analisis terhadap kandungan lemak padat (SFC) oleogel dari berbagai perlakuan oleogelasi menunjukkan bahwa terdapat perbedaan antara SFC oleogel yang digelasi dengan minyak kedelai maupun minyak sawit. Tingkat ketelitian dari hasil analisis sampel dengan perlakuan penggunaan minyak kedelai $(\mathrm{K})$ menunjukkan bias yang lebih kecil ( $s=2,032)$ dibanding hasil analisis sampel pada perlakuan penggunaan minyak sawit $(s=6,234)$.

Kandungan Lemak Padat (Solid Fat Content) (\%)

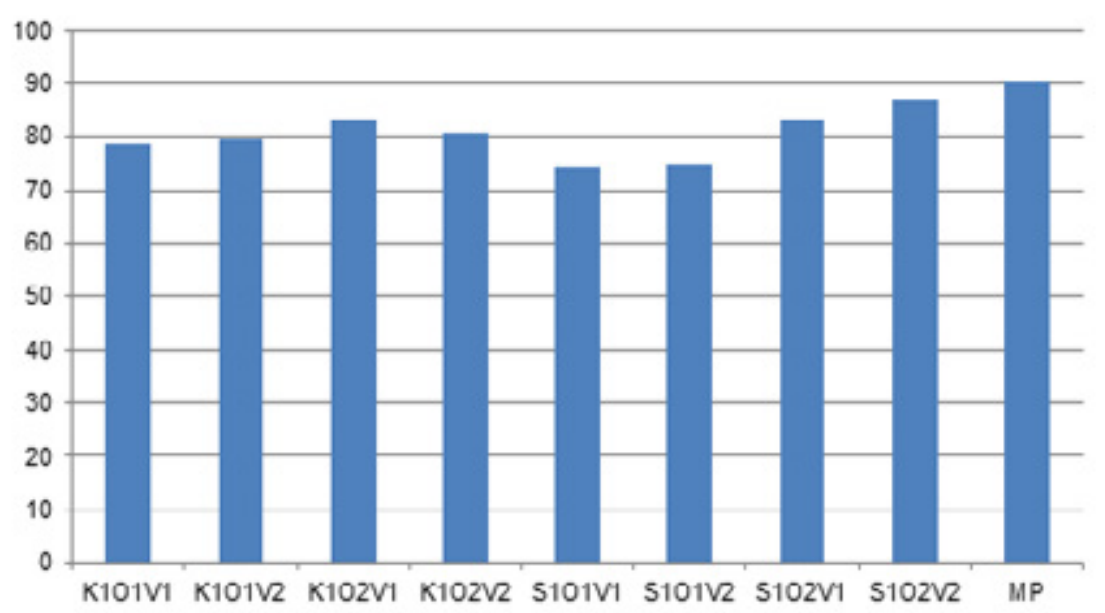

Gambar 4. Kandungan lemak padat (solid fat content) Oleogel dari berbagai perlakuan oleogasi

Keterangan Gambar :

K1O1V1 $=\quad(90 \%$ minyak kedelai $+1 \%$ lemak kakao $+9 \%$ lilin lebah, diaduk pada kecepatan $1.500 \mathrm{rpm})$ K1O1V2 $=\quad(90 \%$ minyak kedelai $+1 \%$ lemak kakao $+9 \%$ lilin lebah, diaduk pada kecepatan $25.000 \mathrm{rpm})$ $\mathrm{K} 1 \mathrm{O} 2 \mathrm{~V} 1=\quad(90 \%$ minyak kedelai $+3 \%$ lemak kakao $+7 \%$ lilin lebah, diaduk pada kecepatan $1.500 \mathrm{rpm})$ $\mathrm{K} 1 \mathrm{O} 2 \mathrm{~V} 2=\quad(90 \%$ minyak kedelai $+3 \%$ lemak kakao $+7 \%$ lilin lebah, diaduk pada kecepatan $25.000 \mathrm{rpm})$ S1O1V1 $=\quad(90 \%$ minyak sawit $+1 \%$ lemak kakao $+9 \%$ lilin lebah, diaduk pada kecepatan $1.500 \mathrm{rpm})$ S1O1V2 $=(90 \%$ minyak sawit $+1 \%$ lemak kakao $+9 \%$ lilin lebah, diaduk pada kecepatan $25.000 \mathrm{rpm})$ S1O2V1 $=\quad(90 \%$ minyak sawit $+3 \%$ lemak kakao $+7 \%$ lilin lebah, diaduk pada kecepatan $1.500 \mathrm{rpm})$ $\mathrm{S} 1 \mathrm{O} 2 \mathrm{~V} 2=\quad(90 \%$ minyak sawit $+1 \%$ lemak kakao $+9 \%$ lilin lebah, diaduk pada kecepatan $25.000 \mathrm{rpm})$. $\mathrm{MP}=$ Mentega Putih sebagai pembanding

Gambar 4, memperlihatkan bahwa kecepatan pengadukan tidak mempengaruhi kandungan SFC oleogel dari minyak kedelai yang digelasi dengan oleogelator $1 \%$ lemak kakao dan 9\% lilin lebah (K101V1 dan K1O1V2), tetapi hasil digelasi minyak kedelai dengan oleogelator $(3 \%$ lemak kakao dan $7 \%$ lilin lebah) menunjukkan nilai SFC yang lebih tinggi pada kecepatan pengadukan $1.500 \mathrm{rpm}$ dan menurun pada kecepatan pengadukan $25.000 \mathrm{rpm}$ (K1O2V1 dan K1O2V2). Hal ini menunjukkan bahwa, pada kecepatan pengadukan yang rendah (1.500 rpm), lemak kakao (3\%) dan lilin lebah $7 \%$ belum teremulsi secara sempurna yang berakibat pada tingginya FSC (sampel K2O2V1), sedangkan pada kecepatan $25.000 \mathrm{rpm}$ terjadi peningkatan penguraian oleogeator menjadi emulsi yang stabil menyebabkan SFC menurun (sampel 
K2O2V2). Selain itu, komposisi lemak kakao $3 \%$ sebagai oleogelator, memberi kontribusi terhadap kandungan lemak padat oleogel. Walaupun tidak mempengaruhi struktur oleogel, kehadiran lemak kakao dalam proses oleogelasi dapat menjadi keseimbangan dalam mempertahankan elastisitas dan sifat gelatinasi maupun dalam membentuk struktur oleogel.

Pengadukan dengan kecepatan tinggi cenderung menghasilkan tumbukan yang lebih besar pada molekul sehingga memungkinkan material lilin lebah dan lemak kakao lebih mudah terinklusi satu dengan yang lainnya membentuk kristal molekul baru yang lebih stabil dan homogen, walaupun pada beberapa kasus, tumbukan yang terlalu besar dan terlalu lama akan memutuskan ikatan suatu molekul yang terstruktur dan kembali menjadi molekul awal.

Oleogelasi minyak sawit dengan olegelator $3 \%$ lemak kakao dan $7 \%$ lilin lebah (Gambar 4) contoh sampel S1O2V1 dan S1O2V2), cenderung menghasilkan oleogel dengan kandungan SFC yang tertinggi. Terdapat perbedaan pada perlakuan pengadukan, dimana semakin tinggi kecepatan pengadukan, kadar SFC semakin meningkat. Hal ini menunjukkan bahwa kontribusi 3\% lemak kakao ditunjang dengan dominasi lemak jenuh pada minyak sawit (asam palmitat 44-45\%, asam oleat $39-40 \%$, asam linoleat $10-11 \%$ dan sejumlah kecil asam linolenat) (Gunstone, 2002) menyebabkan SFC meningkat, bila dibanding dengan minyak kedelai yang didominasi oleh asam lemak tidak jenuh mencapai 87-93\% (Tuminah, 2009).

Penambahan lemak kakao dalam komposisi oleogelator dapat mempengaruhi kandungan SFC, namun keberadaannya dapat menjadi keseimbangan dalam mempertahankan elastisitas dan sifat gelatinasi maupun dalam membentuk struktur oleogel. Bila dibandingkan dengan mentega putih (MP), kandungan lemak padat oleogel dari berbagai perlakuan masih berada di bawah sampel standar mentega putih (MP). Hal ini disebabkan karena 90 $\%$ bahan pembentuk oleogel berada dalam bentuk fraksi minyak berupa asam oleat dan lenolenat, dan $10 \%$ dalam bentuk fraksi padat berupa asam stearat, palmintat dan laurat.

Variasi kandungan lemak padat (SFC) oleogel yang dihasilkan dari berbagai perlakuan pada penelitian ini dapat dijadikan acuan untuk pengembangan tipe dan jenis produk sesuai dengan karakteristik oleogel yang dihasilkan.

\section{KESIMPULAN}

Data karakteristik menunjukkan bahwa oleogel dapat dirancang dari minyak nabati seperti minyak sawit dan kedelai dengan oleogelator lemak kakao dan lilin lebah.

Oleogel yang dihasilkan dari oleogelasi minyak sawit dan minyak kedelai dengan oleogelator atau gelator lemak kakao dan lilin lebah menunjukkan karakteristik yang berbeda-beda, sehingga aplikasinya akan disesuaikan dengan sifat-sifat oleogel tersebut.

Karakteristik yang diperoleh adalah; memiliki titik leleh dan viskositas yang tinggi yaitu $43,72-45,53^{\circ} \mathrm{C}$ dan $161 \times 10^{3}$ centipoise, kandungan lemak padat yang rendah $(83,33 \%)$, dan mempunyai struktur yang lebih padat dan homogen.

Oleogel dengan karakteristik terbaik diperoleh dari proses oleogelasi dengan minyak sawit dan oleogelator $(1 \%$ lemak kakao dan $9 \%$ lilin lebah) pada kecepatan pengadukan $25.000 \mathrm{rpm}$.

\section{DAFTAR PUSTAKA}

1. Dassanayake, L.S.K., Kodali, D.R., Ueno, S., Sato, K., 2009. Physical Properties of Rice Bran Wax in Bulk and Organanogels. J Am. Chem. Soc. 86. 1163-73.

2. Dassanayake, L.S.K., Kodali, D.R., Ueno, S., 2011. Formation of Oleogel based on Edible Lipid Materials. Current Oppinion in Colloidal\&Interface Science 16. 432-439.

3. Davidovich, P.M., Barbut, S., \& Marangoni, A. G., 2016. Development, Characteri- 
zation and Utilization of Food-Grade Polymer Oleogels, Annu. Rev. Food Sci. Technol. (December 2015).

4. Doan, C.D., Tavernier, I., Okuro, P.K., \& Dewettinck, K., 2018. Internal and External Factor Affecting the Crystallization, Gelation and Application of Wax-Based Oleogel in Food Industry. Food Science \& Emerging Technologys. Volume 45, Februari 2018. Pages $42-52$.

5. Gunstone, F.D., 2002. Vegetable Oil in Food Technology: Composition, Properties and Uses. Blachwell Publishing. Hal 59-93.

6. Kodali D. R., 2009. The Utilization of Rice Bran Wax to Stabilize Long Chain $\omega-3$ Polyunsaturated Fatty Acid Esters. Lipid Technol., 21, 254-6

7. Kraft, J. N., \& Lynde, C. W., 2005. Moisturizers: what they are and a practical approach to product selection. Skin Therapy Lett, 10(5), 1-8.

8. Marangoni A.G, Garti N., 2011. Edible Oleogels: Structure and Health Implications. Urbana: AOCS Pres

9. Marangoni, A. G., 2012. Organogels: An Alternative Edible Oil-Structuring Method, J. Am. Oil Chem. Soc. 89:749-80.

10. Narine, S.S., Marangoni, A.G.,1999. Mechanical and Structural Model of Fractal Networks of Fat Crystals at Low Deformations. J. Am. Phys. Soc. 60, 6991e7000.

11. Ogutcu, M., Arifoglu, N., Yılmaz, E., 2015. Preparation and Characterization of Virgin Olive Oil Bees Wax Oleogel Emulsion Products. J. Am. Oil Chem. Soc. 92, 459e471.

12. Nasir, M. A. S. M., 2005. Taxonomic Perspective of Plant Species Yielding Vegetable Oils used in Cosmetics and Skin Care Products. African Journal of Biotechnology, 4(1), 36.

13. Ross, J., 2000. Cocoa and Chocolate as Functional Foods, Journal of Medical Food, Vol.3. No. 2. 2000.

14. Samuditha, L., Dassanayake, K., Kodali, D. R., \& Ueno, S., 2011. Current Opinion in Colloid \& Interface Science
Formation of Oleogels based on Edible Lipid Materials. Current Opi-nion in Colloid \& Interface Science, 16(5), 432-439.

15. Toro-Vazquez JF, Morales-Rueda JA, Dibildox-Alvarado $\mathrm{E}$, Char' o-Alonso M, Alonzo-Macias M, Gonz'alezCh'avezM.M., 2007. Thermal and Textural Properties of Organogels Developed by Candelilla Wax in San Flower Oil. J. Am. Chem. Soc. 84:989-1000

16. Toro-Vazquez, J.F., Morales-Rueda, J., Torres-Martínez, A., Char_o-Alonso, M.A., Mallia, V.A.,Weiss, R.G., 2013. Cooling Rate Effects on the Microstructure, Solid Content, and Rheological Propertiesof Orga-nogels of Amides Derived from Stearic and (R)12-Hydroxy Stearic Acid in Vegetable Oil. Langmuir29, 7642e7654.

17. Tuminah, S., 2009. Efek Asam Lemak Jenuh dan Asam Lemak Tidak Jenuh "Trans" terhadap Kesehatan. Media Penelitian dan Pengembangan Kesehatan. Volume XIX Tahun 2009, Suplemen II. Hal. S13-S20.

18. Van, D., 2016. Edible Applications of Shellac Oleogels: Spreads, Chocolate Paste and Cakes, (March 2014). doi:10.1039/c4fo00034j

19. Venter, M.J., Schouten, N., Hink, R., Kuipers, N., de Haan, A.B., 2007. Expression of Cocoa Butter from Cocoa Nibs. Separation and Purification Technology 55(2), 256-264

20. Wassell P, Bonwick G, Smith CJ, Almiron-Roig E, YoungN.W.G., 2010. Towards a Multidisciplinary Approach to Structuring in Reduced Saturated Fat-Based Systems: a Review. Int. J. Food Sci. Technol. 45:642-55

21. Wulandari, et al., 2011. Karakteristik Fisikawi dan Kimiawi Minyak Kelapa Sawit dan Minyak Bekatul serta Kandungan Gizinya. Kabar Pangan Pertanian.(http://pengetahuan pangan pertanian.blog.spot.com/2016/04/karakteristik-fisikawi-dan-kimiawi. html. Diakses: 23 Agustus 2019. 